Suradinata, Y. R A. Nuraini $\cdot$ A. Sela

\title{
Respons bunga anggrek Dendrobium F1 (Dendrobium Malaysian Green) pada berbagai konsentrasi giberelin
}

\section{Response of F1 Dendorbium flower (Dendrobium Malaysian Green) to various gibberellin concentration}

Diterima : 15 Februari 2016/Disetujui : 1 Maret 2016 / Dipublikasikan : Maret 2016

CDepartment of Crop Science, Padjadjaran University

\begin{abstract}
The experiment to find out the response of Dendrobium 'Malaysian Green' flower to application of several $\mathrm{GA}_{3}$ concentrations. The experiment was conducted from January to April 2015 in Cibiru District, Bandung City with an altitude 740 metre above the sea level. The experimental designwas used the Randomized Block Design with descriptive analysis which consist six treatments. These treatments were :without $\mathrm{GA}_{3}, \mathrm{GA}_{3} 75 \mathrm{ppm}, \mathrm{GA}_{3}$ 100 ppm, $\mathrm{GA}_{3} 125$ ppm, $\mathrm{GA}_{3} 150$ ppm, and $\mathrm{GA}_{3}$ $175 \mathrm{ppm}$. The $\mathrm{GA}_{3}$ application performed three times at intervals of seven days with spraying dosage $23 \mathrm{ml}$ for each plant. The application of $\mathrm{GA}_{3} 125 \mathrm{ppm}$, gave a longer flower stalk, higher flower number, and bigger flower diameter than without $\mathrm{GA}_{3}$.
\end{abstract}

Keywords : Flower diameter $\cdot \mathrm{GA}_{3} \cdot$ Flower stalk - Number of flower · Vaselife

Sari. Percobaan ini bertujuan untuk mengetahui respons bunga Dendrobium 'Malaysian green' pada pemberian beberapa konsentrasi $\mathrm{GA}_{3}$. Percobaan dilakukan pada bulan Januari 2015 hingga April 2015, di Cibiru, Bandung pada ketinggian tempat 740 meter di atas permukaan laut. Percobaan ini menggunakan Rancangan Acak Kelompok dengan analisis deskriptif yang terdri dari enam perlakuan, yaitu : Tanpa pemberian $\mathrm{GA}_{3}$ sebagai kontrol, $\mathrm{GA}_{3} 75 \mathrm{ppm}$, $\mathrm{GA}_{3} 100$ ppm, GA 125 ppm, GA 150 ppm, dan $\mathrm{GA}_{3} 175 \mathrm{ppm}$. Pemberian $\mathrm{GA}_{3}$ dilakukan sebanyak tiga kali dengan interval aplikasi tujuh hari sekali dengan dosis penyemprotan $23 \mathrm{ml}$

\footnotetext{
Dikomunikasikan oleh Yudithia Maxiselly

Suradinata, Y. R ${ }^{1} \cdot$ A. Nuraini ${ }^{1} \cdot$ A. Sela ${ }^{2}$

1Staf Pengajar Program Studi Agroteknologi Fakultas

Pertanian Universitas Padjadjaran.

2Alumni Fakultas Pertanian Universitas Padjadjaran.

Korespondensi: dryayat_effendi@yahoo.com
}

per tanaman. Penggunaan $\mathrm{GA}_{3} 125$ ppm dapat memperpanjang tangkai bunga, memperbanyak jumlah kuntum bunga, dan memperbesar diameter bunga Dendrobium dibandingkan dengan tanpa $\mathrm{GA}_{3}$.

Kata kunci : Diameter bunga $\cdot \mathrm{GA}_{3} \cdot \mathrm{Jumlah}$ kuntum · Lama kesegaran bunga $\cdot$ Tangkai bunga

\section{Pendahuluan}

Anggrek adalah salah satu komoditas bunga potong yang diminati banyak konsumen selain mawar, krisan, dan sedap malam. Walaupun produksi bunga potong anggrek di Indonesia pada tahun 2012 lebih rendah dibanding produksi bunga mawar, krisan, dan sedap malam. Peningkatan produksi bunga potong anggrek Indonesia sejak tahun 2010 sampai 2012 meningkat dari 14.050 .445 tangkai menjadi 15.490.256 tangkai pada tahun 2011 dan 20.714.137 tangkai pada tahun 2012 (Badan Pusat Statistik, 2013).

Menurut Widiastoety dkk. (2010) anggrek merupakan tanaman hias yang memiliki pasar konsumen relatif stabil tidak tergantung musim. Walaupun banyak genus anggrek yang ada, konsumen lebih cenderung memilih anggrek dari genus Phalaenopsis, Cattleya, Dendrobium, Oncidium, dan Vanda dibandingkan genus Luisia, Eria, dan Cryptostylis karena perawatannya relatif mudah, lebih mudah dibungakan, dan memliki lebih banyak variasi bunga. Dendrobium adalah salah satu anggrek yang memiliki banyak peminat karena relatif mudah beradaptasi di dataran rendah, tidak terlalu memerlukan perawatan khusus, mudah berbunga, memiliki banyak variasi bunga, dan beberapa jenis hibrida yang bunganya tetap harum. Umumnya 
konsumen menghendaki tanaman yang sudah atau siap berbunga untuk dibeli sehingga dapat segera menikmati keindahannya tanpa harus repot merawatnya hingga berbunga, oleh sebab itu penjual anggrek kebanyakan hanya menjual tanaman yang telah atau siap berbunga untuk menarik konsumen, dimana presentasi tanaman menjadi faktor penting dalam penilaian konsumen.

Anggrek Dendrobium mampu memenuhi tuntutan perubahan selera konsumen dari waktu ke waktu. Selera konsumen terhadap Dendrobium ditentukan oleh warna, ukuran, bentuk, susunan, jumlah kuntum per tangkai, panjang tangkai, dan daya tahan kesegaran bungaSelain itu juga dipengaruhi oleh produsen dan tren di luar negeri.Tingkatan warna anggrek Dendrobium sangat bervariasi. Umumnya, anggrek hibrida berwarna lembayung muda, putih, kuning keemasan atau kombinasi dari warna-warna tersebut. Beberapa hasil persilangan (hibrida) Dendrobium hasil pemuliaan modern memiliki warna kebiruan, gading, atau jingga tua sampai merah tua (Widiastoety dkk., 2010), selain itu, tanaman anggrek Dendrobium sebagai sumber genetik banyak dijumpai di hutan belantara, namun potensi tersebut belum dimanfaatkan secara optimal. Baru sebagian kecil anggrek alam yang dimanfaatkan sebagai induk persilangan, antara lain karena terbatasnya pengetahuan mengenai sifat-sifat penurunannya. Sebagian besar sumber daya genetik tersebut belum dimanfaatkan sebagai induk silangan. Dendrobium merupakan jenis anggrek alam yang menarik perhatian para penyilang untuk dirakit menjadi varietas baru.

Selain presentasi bentuk dan warna, anggrek dengan tampilan kualitas bunga yang baik, lebih menarik konsumen, sehingga anggrek lain yang memiliki kualitas kurang baik lebih sulit terjual, dan tidak jarang bunganya sudah layu sebelum terjual. Upaya peningkatan kualitas bunga dapat dilakukan dengan penggunaan zat pengatur tumbuh (ZPT), salah satunya adalah Giberelin $\left(\mathrm{GA}_{3}\right)$. Penggunaan $\mathrm{GA}_{3}$ banyak dilakukan untuk meningkatkan kualitas banyak tanaman hias. Aplikasi $\mathrm{GA}_{3}$ pada anggrek, diharapkan bunga anggrek yang dihasilkan memiliki kualitas yang memenuhi kriteria selera konsumen.

Pengaruh giberelin terhadap pembungaan tanaman terbukti dalam penelitian pada tanaman Anthurium andreanum cv. Avo Cuba. Purwoko (1997) menyatakan bahwa pemberian
$10 \mathrm{mg} \mathrm{GA}_{3}$ per tanaman, bunga anthurium dapat dipanen 4,5 minggu lebih cepat, tangkai bunga $5,8 \mathrm{~cm}$ lebih panjang, dan jumlah bunga yang dihasilkan 0,5 kuntum lebih banyak.

Menurut Cardoso et al. (2012) aplikasi $\mathrm{GA}_{3} 125 \mathrm{ppm}$ dengan dosis $40 \mathrm{ml}$ per tanaman pada Phalaenopsisdapat mempercepat waktu pembungaan pertama 4-6 bulan, memperpanjang tangkai bunga, memperbanyak jumlah kuntum bunga 3,6 kuntum, dan memperbesar diameter bunga $0,9 \mathrm{~cm}$ dianding dengan tanaman kontrol.

Berdasarkan uraian di atas, maka perlu dilakukan penelitian mengenai pengaruh konsentrasi $\mathrm{GA}_{3}$ terhadap kualitas bunga Dendrobium Malaysian Green, kegunaan pene-litian ini dari segi praktis diharapkan dapat memberikan informasi kepada petani dan instansi terkait dalam hal konsentrasi $\mathrm{GA}_{3}$ yang sesuai untuk memperbaiki kualitas bunga Dendrobium Malaysian Green.

\section{Bahan dan Metode}

Penelitian dilaksanakan di greenhouse anggrek di Kompleks Vijayakusuma, Cibiru, Bandung, Jawa Barat dengan ketinggian tempat $\pm 740 \mathrm{~m}$ di atas permukaan laut pada Januari sampai April 2015.

Bahan yang digunakan adalah tanaman Dendrobium Malaysian Green berumur 18 bulan sebanyak 30 pot (24 pot sebagai tanaman utama, dan 6 pot untuk cadangan), $\mathrm{GA}_{3}$, Insektisida berbahan aktif Deltametrin, Akarisida berbahan aktif Piridaben, Fungisida berbahan aktif Propamokarb hidroklorida, aquades dan air. Alat yang digunakan adalah pot, hand sprayer, paranet, embrat, jangka sorong, penggaris, gelas ukur $50 \mathrm{ml}$ dan $250 \mathrm{ml}$, pipet tetes, thermohygrometer digital, serta alat tulis.

Percobaan dilaksanakan disusun menggunakan rancangan lingkungan Acak Kelompok dan nilai rata-rata data ditampilkan dalam diagram. Perlakuan dalam penelitian ini terdiri dari 6 perlakuan berupa pemberian konsentrasi giberelin $\left(\mathrm{GA}_{3}\right)$ pada tanaman anggrek Dendrobium Malaysian Green berumur 18 bulanyaitu : A : kontrol (tanpa giberelin), B : 75 ppm, C : 100 ppm, D: 125 ppm, E : 150 ppm, dan F : 175 ppm, dilakukan dengan 3 ulangan. Pengamatan parameter dilakukan pada tanaman sampel sebanyak 2 tanaman setiap perlakuan karena keterbatasan tersedianya tanaman yang seragam pada fase generatif. Penyemprotan $\mathrm{GA}_{3}$ diberi- 
kan dengan interval satu minggu dimulai sejak 0 msa, pada fase kuncup bunga menuju anthesis. Aplikasi $\mathrm{GA}_{3}$ dilakukan dengan dosis $23 \mathrm{ml}$ pertanaman.

Pengamatan penunjang dilakukan terhadap : temperatur rata-rata harian $\left({ }^{\circ} \mathrm{C}\right)$, kelembaban ratarata harian (\%), intensitas organisme pengganggu tanaman. Pengamatan utama dilakukan terhadap : pertambahan panjang tangkai bunga $(\mathrm{cm})$, pertambahan jumlah kuntum bunga per tanaman, diameter kuntum bunga saat mekar sempurna (cm), lama kesegaran bunga (hari). Data disajikan dalam bentuk diagram batang dan dijelaskan secara deskriptif karena keterbatasan tanaman seragam yaitu tanaman yang telah memasuki fase berbunga.

\section{Hasil dan Pembahasan}

Temperatur rata-rata harian di dalam greenhouse berkisar $24,8{ }^{\circ} \mathrm{C}$ dengan temperatur tertinggi mencapai $37,1^{\circ} \mathrm{C}$ dan temperatur terendah pada $18,8{ }^{\circ} \mathrm{C}$. Temperatur rata-rata harian selama penelitian lebih rendah $0,2{ }^{\circ} \mathrm{C}$ dibanding temperatur yang dianjurkan oleh Dirjen Hortikultura (2008), yaitu $25-27^{\circ} \mathrm{C}$.

Kelembaban rata-rata harian berkisar antara 63,8 \% dengan kelembaban tertinggi mencapai $100 \%$ dan kelembaban terendah pada 10 $\%$. Kelembaban relatif harian untuk Dendrobium berkisar pada 60-85 \%, sehingga kelembaban rata-rata harian selama penelitian berlangsung masih termasuk dalam kelembaban optimal pertumbuhan Dendrobium (Setiawan dan Setiawan, 2003).

Hama-hama yang menyerang selama penelitian adalah : Kutu daun (Macrosiphum sp.), tungau merah (Tennuipalvus orchidarum). siput (Succinea sp), penyakit yang menyerang adalah hawar bunga akibat cendawan Fusarium sp. yang menyerang kuntum bunga menjadi layu, dengan intensitas serangan di bawah ambang ekonomi.

Pertambahan Panjang Tangkai Bunga. Berdasarkan hasil pengamatan, respon tanaman terhadap konsentrasi $\mathrm{GA}_{3}$ yang diberikan terlihat pada pertambahan panjang tangkai, seperti yang ditunjukkan pada Gambar 1.

Pengaruh aplikasi $\mathrm{GA}_{3} 125$ ppm per tanaman menghasilkan rata-rata pertambahan tangkai bunga terpanjang, yaitu 7,45 cm dengan panjang tangkai $38,55 \mathrm{~cm}$ atau $1,8 \mathrm{~cm}$ lebih panjang dibandingkan panjang tangkai kontrol.
Hasil penelitian ini sesuai dengan hasil penelitian sebelumnya yang menunjukkan bahwa aplikasi $\mathrm{GA}_{3}$ pada Curcuma alismatfolia sebanyak dua kali pada umur empat minggu setelah tanam dengan cara membasahi tunas yang muncul, meningkatkan pertumbuhan perpanjangan sel pada daun, pembungaan, dan tangkai bunga (Khuankaew et al., 2008). Purwoko (1997) menyatakan bahwa pemberian 10 mg $\mathrm{GA}_{3}$ per tanaman satu kali aplikasi seminggu setelah bunga dipanen, Anthurium dapat menghasilkan bunga dengan tangkai 5,8 cm lebih panjang dibandingkan kontrol. Cardoso et al. (2012) menyatakan aplikasi $\mathrm{GA}_{3} 125$ ppm dengan dosis $40 \mathrm{ml}$ per tanaman pada Phalaenopsis berumur delapan bulan, dapat memperpanjang tangkai bunga 25,4 cm dibanding kontrol.

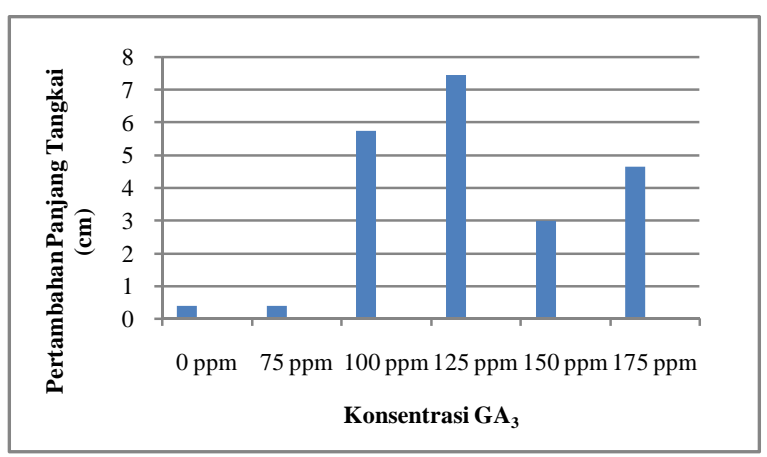

Gambar 1. Diagram Pertambahan Panjang Tangkai Bunga (cm).

Aplikasi $\mathrm{GA}_{3}$ akan menstimulasi perpanjangan sel karena adanya hidrolisa pati yang dihasilkan dari giberelin. Sebagai akibat dari proses tersebut, maka konsentrasi gula meningkat yang mengakibatkan tekanan osmotik di dalam sel menjadi naik, sehingga ada kecenderungan sel tersebut berkembang (Abidin, 1990). Menurut Taiz \& Zeiger (2009 dalam Cardoso et al., 2012), perkembangan sel yang dipengaruhi giberelin melalui aktivasi enzim hirolitik, lebih meningkatkan panjang sel dibanding diameter, sehingga jaringan organ seperti daun, batang, dan buah lebih panjang dan tipis. Selain waktu aplikasi, respon tanaman terhadap hormon eksogen akan berbeda di setiap spesies (Weaver, 1972 dikutip Mubarok, 2006).

Pertambahan Jumlah Kuntum Bunga per Tanaman. Tanaman dengan perlakuan $\mathrm{GA}_{3} 125$ ppm menghasilkan rata-rata pertambahan jumlah kuntum terbanyak dibandingkan perlakuan lain, dengan total bunga 16 kuntum dan 2 kuntum lebih banyak dibandingkan tanaman kontrol (Gambar 2). 
Aplikasi $\mathrm{GA}_{3} 125$ ppm pada Dendrobium menghasilkan jumlah kuntum rata-rata terbanyak, hasil ini didukung oleh penelitian Purwoko (1997) bahwa aplikasi $\mathrm{GA}_{3}$ pada tanaman anthurium menghasilkan bunga ratarata 0,5 kuntum lebih banyak dibandingkan tanaman kontrol, dan penelitian Cardoso et al. (2012) yang menyatakan aplikasi $\mathrm{GA}_{3}$ menghasilkan 3,6 kuntum lebih banyak dibandingkan tanaman kontrol.

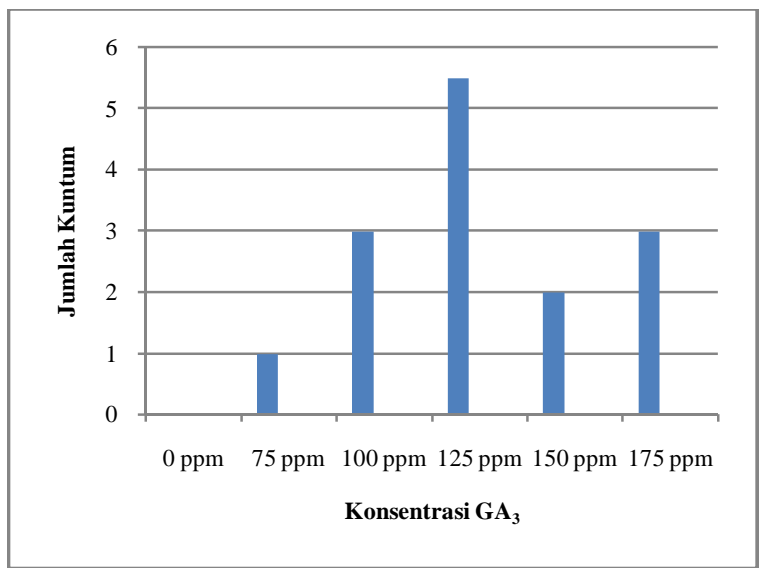

\section{Gambar 2. Diagram Pertambahan Jumlah Kuntum Bunga.}

Pertambahan jumlah kuntum pada perlakuan 150 ppm dan 175 ppm mengalami penurunan dibandingkan perlakuan $125 \mathrm{ppm}$ disebabkan pertambahan jumlah kuntum berkaitan dengan pertambahan panjang tangkai. Aplikasi $\mathrm{GA}_{3} 125$ ppm memperpanjang tangkai bunga sebanyak 7,45 cm dibandingkan dengan aplikasi $\mathrm{GA}_{3} 150$ ppm dan 175 ppm yang hanya memperpanjang tangkai bunga sebanyak 3 dan 4,65 cm. Pada gladiol, peningkatan jumlah kuntum bunga sejalan dengan meningkatnya panjang tangkai daun (Farida dan Hamdani, 2001). Kucup bunga terbentuk seiring bertambahnya panjang tangkai bunga akibat hidrolisa pati yang meningkatkan konsentrasi gula sehingga terjadi peningkatan tekanan osmotik di dalam sel, dan menyebabkan sel tersebut berkembang (Abidin, 1990).

Dibandingkan dengan preferensi konsumen yang menghendaki Dendrobium sebagai bunga pot dengan jumlah kuntum sebanyak 1216 kuntum per tangkai (Nurmalinda dkk., 2011), semua perlakuan memasuki kriteria pilihan konsumen kecuali kelompok tanaman dengan aplikasi $\mathrm{GA}_{3} 125$ ppm.

Diameter Kuntum Bunga. Gambar 3 menunjukkan bahwa diameter kuntum bunga terbesar pada tanaman yang diberi $\mathrm{GA}_{3}$ dengan konsentrasi 125 ppm yaitu 5,16 cm, lebih besar 0,27 cm dibandingkan diameter bunga terbesar pada kontrol tanpa aplikasi $\mathrm{GA}_{3}$. Hasil penelitian ini menunjukkan bahwa pemberian $\mathrm{GA}_{3}$ dengan konsentrasi 125 ppm menghasilkan bunga dengan diameter yang paling besar, hasil penelitian ini sesuai dengan hasil penelitian yang dilakukan oleh Cardoso et al. (2012) yang menunjukkan aplikasi $\mathrm{GA}_{3} 125$ ppm pada Phalaenopsis menghasilkan bunga dengan diameter yang lebih besar dibandingkan dengan kontrol (Cardoso et al., 2012).

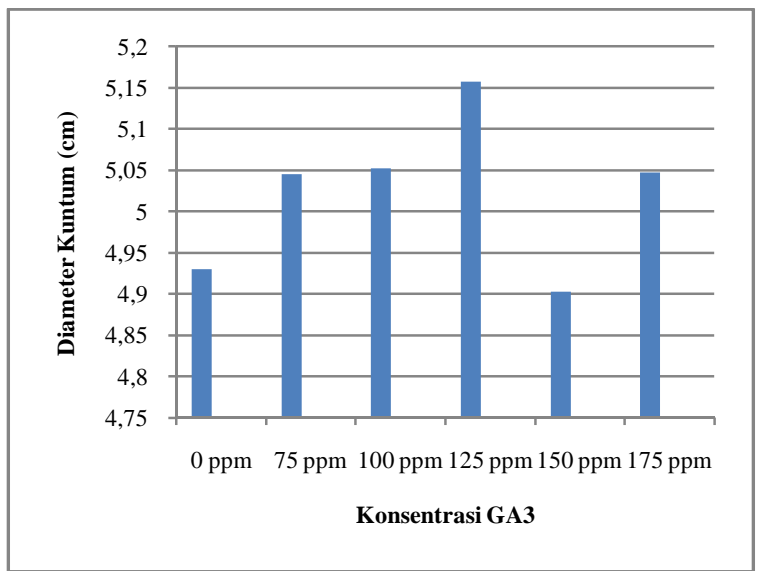

\section{Gambar 3. Diagram Rerata Diameter Kuntum Bunga.}

Kecilnya pengaruh perlakuan $\mathrm{GA}_{3} 125$ ppm terhadap diameter kuntum bunga jika dibandingkan dengan penelitian sebelumnya disebabkan perbedaan fase tumbuh dan usia tanaman. Penelitian milik Cardoso et al. (2012), tanaman yang digunakan berusia 8 bulan dan berada pada fase vegetatif sehingga $\mathrm{GA}_{3}$ yang diserap tanaman dapat merangsang induksi bunga dan berperan dalam proses diferensiasi serta pembelahan sel (Salisbury dan Ross, 1995).

Aplikasi GA $\mathrm{GA}_{3}$ pada konsentrasi 150 dan 175 ppm tidak menghasikan bunga dengan diameter yang besar dibandingkan $\mathrm{GA}_{3}$ dengan konsentrasi 125 ppm, hal ini disebabkan oleh fitotoksisitas aplikasi $\mathrm{GA}_{3}$ dengan konsentrasi tinggi yang memicu pengurangan diameter kuntum (Cardoso et al., 2012). Fitotoksisitas terjadi akibat bahan kimia atau senyawa lainnya pada tingkatan tertentu menjadi racun bagi tanaman. Pengaruh fitotoksisitas $\mathrm{GA}_{3}$ pada mustard dengan konsentrasi 75 ppm, menyebabkan pertambahan tinggi yang lebih sedikit dibandingkan $\mathrm{GA}_{3}$ dengan konsentrasi 50 ppm (Akter et al., 2007). 
Lama Kesegaran Bunga. Selama percobaan, proses layu bunga ditandai dengan penurunan diameter bunga, berubahnya warna sepal dan petal bunga dari hijau kekuningan menjadi lebih pucat dan dominan kuning, serta menyebarnya corak ungu-cokelat kemerahan ke seluruh permukaan lidah. Sejak menunjukkan tanda-tanda layu, bunga akan tetap berada pada tangkai selama delapan hari sebelum rontok, dimana sepal, petal, dan lidah perlahan mengering sehingga kuntum bunga menghadap ke bawah dengan tangkai kuntum yang tetap tegak tidak mengalami perubahan sudut kulai bunga seperti ditunjukkan pada Gambar 4. Tahap layu bunga ditandai dengan proses perubahan warna menjadi lebih pudar dan hilangnya turgiditas sel hingga pada akhirnya menyebabkan bunga rontok (van Doorn, 2008 dikutip Mubarok, 2012).

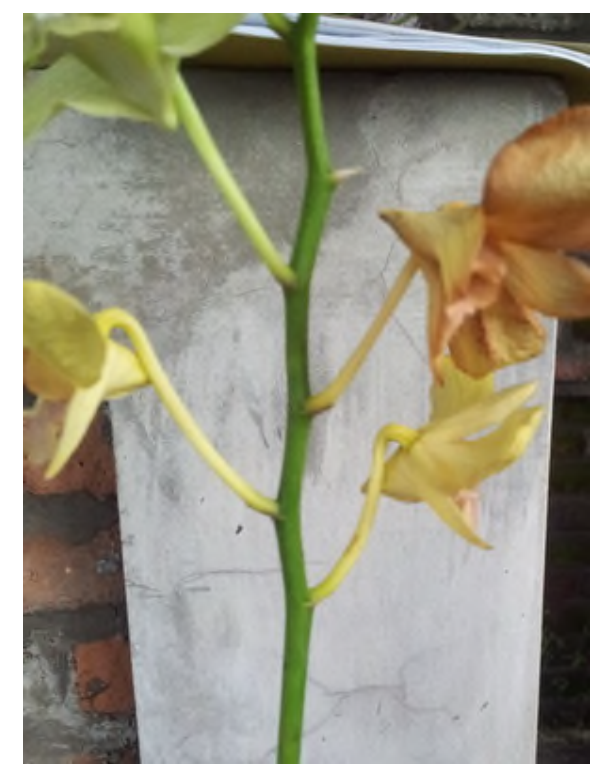

\section{Gambar 4. Tangkai Kuntum Saat Bunga Layu.}

Berdasarkan hasil pengamatan, respon kesegaran bunga dari aplikasi berbagai konsentrasi $\mathrm{GA}_{3}$ selama penelitian menunjukkan hasil yang tidak lebih baik dibandingkan dengan tanaman kontrol, seperti yang ditunjukkan pada Gambar 4.

Kelompok tanaman kontrol memiliki usia kesegaran rata-rata lebih lama dibanding dengan kelompok tanaman yang mendapatkan perlakuan $\mathrm{GA}_{3}$. Lama kesegaran bunga terbaik pada kelompok dengan perlakuan $\mathrm{GA}_{3}$ masih lebih cepat layu 7,25 hari dibanding tanaman yang tidak mendapatkan perlakuan $\mathrm{GA}_{3}$. Lama kesegaran bunga yang lebih pendek dibanding- kan kelompok kontrol, disebabkan oleh tipisnya jaringan kelopak bunga akibat perkembangan sel yang dipengaruhi giberelin melalui aktivasi enzim hirolitik, lebih meningkatkan panjang sel dibanding diameter (Taiz dan Zeiger, 2009 dikutip Cardoso et al., 2012).

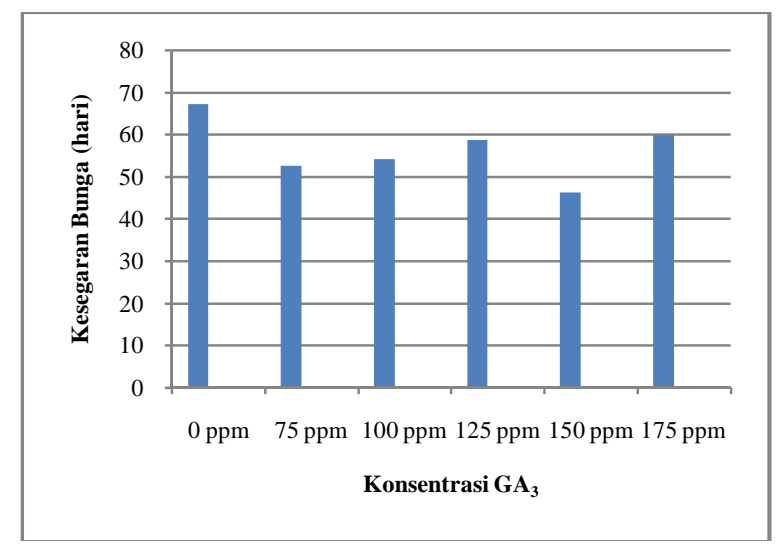

Gambar 5. Diagram Rerata Kesegaran Bunga.

Selama proses transpirasi, sekitar $98,9 \%$ air yang diserap tanaman ditranspirasikan melalui stomata (Prihandarini, 2010). Penyebaran stomata pada bunga anggrek dapat ditemukan pada bagian petal, tudung polen, dan column. Pada petal, stomata dapat ditemukan pada permukaan atas, permukaan bawah, atau keduanya, dan tersebar pada seluruh permukaan atau terpusat pada satu bagian (Hew \& Yong, 2004).Tanaman yang diberi perlakuan $\mathrm{GA}_{3}$ memiliki rata-rata diameter kuntum yang lebih besar, sehingga semakin besar luas permukaan kuntum yang mengalami transpirasi dibandingkan dengan kelompok tanpa $\mathrm{GA}_{3}$. Pobudkiewicz dan Nowak (1992 dalam Małgorzata et al., 2013) menyatakan bahwa aplikasi $\mathrm{GA}_{3}$ meningkatkan diameter kuntum tetapi memperpendek usia kesegaran bunga pada Gerbera jamesonii, hal ini disebabkan oleh aplikasi $\mathrm{GA}_{3}$ yang menghasilkan respon berbeda di setiap tanaman terhadap tergantung kultivar, dosis, konsentrasi, dan waktu aplikasi. Saifuddin et al. (2014) menyatakan bahwa aplikasi $\mathrm{GA}_{3} 100$ ppm dapat meningkatkan diameter bunga dan mengurangi usia kesegaran bunga Hibiscus sp. sebanyak tiga hari lebih cepat layu dibandingkan dengan kontrol. Pertambahan diameter bunga berbanding terbalik dengan lama kesegaran bunga. Semakin tinggi pertambahan diameter bunga, maka kesegaran bunga akan semakin berkurang, semakin kecil pertambahan diameter bunga, maka kesegaran bunga semakin lama (Suradinata, 2015). 
Tidak efektifnya aplikasi $\mathrm{GA}_{3}$ dalam menahan laju senesen menunjukkan bahwa aplikasi $\mathrm{GA}_{3}$ tidak berperan dalam mencegah penurunan kandungan amilum, polisakarida dinding sel, protein, dan asam nukleat, serta tidak dapat menahan laju peningkatan aktivitas enzim peroksidase yang terlibat dalam perang-sangan senesen dan perangsangan pembentukan etilen. Terbentuknya etilen menyebabkan bunga mengalami peningkatan laju senesen (Abidin, 1990), sehingga mengurangi daya tahan komoditas.

\section{Kesimpulan}

Kesimpulan dari perlakuan Konsentrasi Giberelin berpengaruh terhadap parameter kualitas bunga Dendrobium Malaysian Green. Aplikasi $\mathrm{GA}_{3}$ dengan konsentrasi 125 ppm per tanaman sebanyak tiga kali dengan interval penyemprotan satu minggu dan dosis aplikasi $23 \mathrm{ml}$ per tanaman, berpengaruh terhadap beberapa parameter kualitas bunga, yaitu : panjang tangkai bunga, jumlah kuntum, dan diameter kuntum yang lebih besar dibandingkan tanaman kontrol, tetapi respons kesegaran bunga dengan aplikasi $\mathrm{GA}_{3}$ tidak lebih baik dibandingkan tanaman kontrol.

\section{Daftar Pustaka}

Akter A., A. E. Islam, M.M.Z. Karim, and R. Razzaque. 2007.Effect of $\mathrm{GA}_{3}$ on growth and yield of mustard. Int. J. Sustain. Crop Prod. 2(2):16-20

Badan Pusat Statistik. 2013. Produksi tanaman hias di Indonesia, 1997-2012. Diakses melalui www.bps.go.id pada Mei 2013.

Cardoso, J., E. Ono, and J. Rodrigues. 2012. Gibberellic acid in vegetative and reproductive development of Phalaenopsis orchid hybrid genus. Horticultura Brasileira 30: 71-74.

C.S. Hew and J.W.H. Yong. 2004. The physiological of tropical orchids in relation to the industry. World Scientific Publishing Co. Pte.Ltd.

Dirjen Hortikultura. 2008. Standard prosedur operasional anggrek dendrobium. Departemen Pertanian.

Farida, dan J.S Hamdani. 2001.Pertumbuhan dan hasil bunga gladiol pada dosis pupuk organik bokashi dan dosis pupuk nitrogen yang berbeda. Jurnal Nionatura, Vol.3, No. 2 (1): 68-76.
Khuankaew, T., T. Ohyama, and S. Ruamrungsri. 2008. Effects of gibberellin application on growth and development of Curcuma alismatifolia Gagnep. Bulletin Faculty Agriculture Niigata University 60 (2): 135140.

Małgorzata, Z., and A. Małgorzata. 2013. Gibberellic acid effet ongrowth and flowering of Ajania pacifica /Nakai/ bremer et humphries. Journal of Horticurtural Research vol. 21 (1) : 21-27.

Mubarok, S. 2006. Pengaruh Kombinasi Konsentrasi dan Interval Pemberian $\mathrm{GA}_{3}$ terhadap Pertumbuhan Dan Kualitas Bunga Krisan Potong (Chrysanthemum morifolium Ramat.) Kultivar Shamrock Di Dataran Medium Tasikmalaya. Bandung: Universitas Padjadjaran.

Mubarok, S. 2012. Kualitas bunga krisan potong 'Yellow Fiji" sebagai respon dari aplikasi 1Methylcyclopropene. J.Agrivigor 11(2) : 244250.

Nurmalinda, S., N.Q Kartikaningrum dan D. Widyastoety. 2011. Prefenrensi konsumenterhadap anggrek Phalaenopsis, Vanda, dan Dendrobium. Jurnal Hortikultira, 21(4) : 372-384.

Prihandarini, R. 2010. Fisiologi tumbuhan. Malang: Universitas Widyagama.

Purwoko, B.S., D.S Sulistuyani dan L.W Gunawan. 1997. Pengaruh aplikasi GA terhadap pembungaan tanaman Anthurium andreanum cv. Avo Cuba.Jurnal Agronomi Indonesia (Indonesian Journal of Agronomy),25(3) : 20-24.

Saifuddin, M., M.K Moneruzzaman, M.J Sarwar, Nashriyah, and S Hossain. 2014. Size enlargement and shorten longevity of Hibiscus flower affected by gibberellin acid and aluminium sulphate using dripping technique. Asian Network for Scientific Information.

Salisbury, F.B dan C.W. Ross. 1995. Fisiologi Tumbuhan. Terjemahan oleh Diah R. Lukman dan Sumaryono. Bandung: ITB.

Setiawan, H dan L. Setiawan. 2003. Merawat phalaenopsis.Depok: Penebar Swadaya.

Soeryowinoto, S.M. 1974. Merawat Anggrek. Kanisius.

Suradinata, Y.R. 2015. Rekayasa tanaman mawar: menjadi tanaman mawar pot dengan aplikasi zat perangsang tumbuh paklobutrazol dan 1methylcyclopropene (1-MCP). Bandung: Pustaka Giratuna. 
Suyitno A dan Ratnawati. 2004. Respon konduktivitas stomata dan laju transpirasi Rumput Blemberm (Ischaemum liliare, Retzius) di sekitar sumber emisi gas Kawah Sikidang, Dieng. Yogyakarta: UNY.

Utami, A.S. 2010.Respon pertumbuhan bibit sukun (Artocarpus communis. Forst) pada intensitas penyiraman berbeda. Universitas Sumatera Utara

Widiastoety, D., N. Solvia, N., dan M. Soedarjo. 2010.Potensi anggrek Dendrobium dalam meningkatkan variasi dan kualitas anggek bunga potong. Jurnal Litbang Pertanian 29 (3) : 101-106. 